$$
\begin{aligned}
& \text { S39.313 Defore the } \\
& \text { F2bmpff Montana Board of } \\
& 1992 \text { Natural Resources } \\
& \text { and Conservation } \\
& \text { in the matter of } \\
& \text { water reservation }
\end{aligned}
$$

:


MANTAMA CTATE I IODADV

MONTANA STATE LIBRARY

30864001486904 


\section{MUN 031992}

Curtis E. Larsen

Robert $N$. Lane

MONTANA STATE LIBRARY

1515 E. Gth AVE.

HELENA, MONTANA 59620

Montana Department of

Fish, Wildlife and Parks

1420 East Sixth Avenue

Helena, MT 59620

(406) 444-4594

BEFORE THE MONTANA BOARD OF NATURAL

RESOURCES AND CONSERVATION

IN THE MATTER OF WATER

RESERVATION APPLICATION NOS.

69903-410 71895-4II 72578-4IL

70115-41F 71966-41S 71579-41T

$70117-41 \mathrm{H} 71997-41 \mathrm{~J}$ 72580-41A

70118-41H 71998-41S 72581-4II

70119-41H 72153-41P 72582-4II

70270-41B 72154-41K 72583-41P

71537-41P 72155-41A 72584-41S

71688-41L 72256-41P 72585-41M

$71889-41 \mathrm{Q}$ 72307-41Q 72586-41P

$71890-41 \mathrm{~K} \quad 72574-410 \quad 72587-41 \mathrm{G}$

71891-41P 72575-41K 72588-40C

$71892-41 \mathrm{G} 72576-40 \mathrm{E}$ 73198-4II

71893-41K 72577-41P 73199-41S

71894-4II IN THE UPPER

MISSOURI RIVER BASIN

BRIEF OF DFWP IN SUPPORT OF ITS INSTREAM APPLICATIONS AND IN OPPOSITION TO THE $\begin{array}{lllllllllll}R & E & S & E & \boldsymbol{V} & A & T & I & O & N\end{array}$ APPLICATIONS OF THE CONSERVATION DISTRICTS, THE B URE A U OF RECLAMATION AND THE CITY OF BOZEMAN

\section{INTRODUCTION}

The Department of Fish, Wildlife and Parks (DFWP) application for instream reservations on 281 stream reaches, one lake, and one swamp in the Missouri River Basin above Fort Peck Dam meet the criteria established by statute, ARM 85-2-316, MCA, and by rule, ARM 36.16.107B, and, therefore, these instream reservation applications should be granted by the Board of Natural Resources and Conservation (Board). The most significant positions taken and 
Digitized by the Internet Archive in 2017 with funding from Montana State Library 
issues argued in this brief are outlined in this introduction.

DFWP is a qualified applicant applying for instream reservations to protect fishery, wildlife and recreational values which are beneficial uses. The flows requested are needed because the fishery, wildlife and recreational values warrant protection. The amount of the instream requests were established by the Wetted Perimeter Method and other methods which have been established as accurate and suitable methods.

The instream reservations are in the public interest based on a weighing and balancing of the required factors, including a conservative benefit and cost comparison to competing consumptive reservation requests for irrigation. A conservative, but realistic, value of 75 mills per kilowatt-hour as the replacement cost for lost hydropower generation was used in the analysis. The instream benefits outweigh the costs when compared to competing consumptive reservations for all irrigation projects except eleven projects. These eleven projects fail to meet other public interest criteria, primarily because of adverse environmental impacts that cannot be quantified in monetary terms, and they will adversely affect claimed existing water rights. Further, the value of protecting resources on streams where there is no competition from a present reservation request is included as a benefit of those instream reservations.

The DFWP has a management plan demonstrating its capacity to diligently monitor and protect the instream reservations. The instream reservations can only preserve the status quo up to the 

minimum flow needed to sustain a healthy fishery. They do not consume or divert water, are complementary with any other instream uses and downstream uses, and, consequently, cannot adversely affect existing water rights.

Eighteen Conservation Districts have requested reservations for a total of 219 proposed irrigation projects covering 154,604 acres. Except for eleven projects, the costs outweigh the benefits when compared to competing uses, including instream reservations for recreation and downstream hydropower generation, for all of the proposed irrigation projects. The value of the water for irrigation projects were calculated using a number of assumptions favorable to the irrigation projects.

However, the eleven projects, that initially pass the benefit/cost test, do not pass other public interest criteria and, therefore, should not be granted reservations. Reservations for projects that are at least marginally feasible could be granted with priorities junior to the instream reservations, provided they would not significantly impact the instream reservations, do not have unacceptable adverse environmental impacts, and do not adversely impact existing water rights. Many of the irrigation projects would adversely impact claimed existing water rights by consuming water needed, at times, for existing uses. These existing rights include senior irrigators, downriver hydropower generation rights held by the Montana Power Company (MPC) and the Bureau of Reclamation (BUREC), instream "Murphy rights" held by DFWP and an instream flow right held by the Bureau of Land 

Management (BLM) for the segment of the Missouri River designated as wild and Scenic.

of the remaining 17 municipalities that applied for water reservations, DFWP is objecting only to the application by the city of Bozeman. The city of Bozeman has failed to show that the amount of water to be supplied by a dam on Sourdough (Bozeman) Creek is needed. The application should be denied, unless sufficiently conditioned, because of the failure to demonstrate a need for the amount and because of adverse environmental impacts of the construction and operation of the proposed dam.

DFWP will address some issues that have been raised already by other parties, such as the significance of water availability to the differing types of reservation requests

\section{FACTS}

The reservations requested by all the applicants have been analyzed by DNRC in a draft environmental impact statement (draft EIS) and a final environmental impact statement (final EIS) and with individual environmental assessments (EAs) for each application. There has been an extensive contested case hearing on all the applications, including prefiled written testimony and exhibits and a hearing at which testimony and exhibits were introduced and witnesses were cross-examined. DFWP is submitting, concurrently with this brief, comprehensive proposed findings of fact, conclusions of $l a w$ and a recommended order. The argument presented here is based on the proposed findings of fact. 



\section{ARGUMENTS}

The statutory criteria of Section 85-2-316(4) (a), MCA, and the rules of the Board, contained primarily in ARM 36.16.107B, implementing the criteria, govern this proceeding. These criteria must be established by the applicant to the satisfaction of the Board before the Board may by order create a reservation of water. Section 85-2-316(4)(a), MCA. The reservation procedure is a contested case under the Montana Administrative Procedures Act, although the formal rules of evidence do not apply. Section 85-2121, MCA.

purpose. The criteria that the purpose of the reservation must be established is defined by two elements -- the applicant must be qualified to reserve water and the purpose of the reservation must be a beneficial use. ARM 36.16.107B(1)(a)\&(b).

There has been no contention that DFWP, or for that matter any of the other applicants, is not a qualified applicant. DFWP, as an executive branch agency of the state, qualifies as an eligible applicant under section 85-2-316(1), MCA. In applying for instream reservations of water, DFWP is fulfilling its mandate, as the representative of the public's interests, to provide for the protection, preservation and propagation of all fish and wildlife and their habitat in the state. Section 87-1-201, MCA.

The instream reservations of water are for the benefit of the public for fish, wildlife and recreational uses. The minimum flow levels would protect the diversity of fish and wildlife species, preserve riparian habitats, protect the environment, help maintain 

water quality, and provide optimum opportunities for diverse outdoor recreation. Fish, wildlife and recreational uses are defined by Board rule as beneficial uses for water reservations. ARM 36.16.102(3). The reservation statute, Section 85-2-316(1), MCA, allows the Board "to reserve waters for existing or future beneficial uses or to maintain a minimum flow, level, or quality of water". Beneficial use, as defined by statute, includes fish and wildlife and recreational uses. Section 85-2-102(2), MCA. There is no doubt that the instream reservation requests of DFWP are for an allowed purpose. In fact, these instream reservations meet the purpose test as both beneficial uses and as maintaining a "minimum flow, level, or quality of water" to protect fish, wildlife and recreation.

Need. The need for the reservation must be established. Section 85-2-316(4)(a)(ii). The Board has determined in ARM $36.16 .107 \mathrm{~B}(2)(\mathrm{b})$ that to establish a reservation is needed it must find:

... Where the applicant may not be eligible to apply for a water use permit, the applicant has demonstrated that the water resource values warrant reserving water for the requested purpose;

DFWP is not eligible to apply for an instream water use permit to protect a minimum flow level for fish, wildlife and recreational purposes. The reservation statute provides specific authority for establishing minimum instream flows. The beneficial water use permit statutes, however, require a person appropriating water for a new beneficial use to obtain a permit through an administrative process before the Department of Natural Resources and Conservation 

(DNRC) - Section 85-2-301, MCA; and generally, Title 85, chapter 2, part 3, MCA. Appropriation is defined, in section 85-2-102(1), MCA, as meaning to:

(a) divert, impound, or withdraw (including by stock for stock water) a quantity of water;

(b) in the case of a public agency, to reserve water in accordance with 85-2-316; or

(c) in the case of the department of fish, wildlife, and parks, to lease water in accordance with 85-2-436. (emphasis added).

Under this definition, a permit cannot be obtained for the use of water as an instream flow. There is no diversion, impoundment or withdrawal when the use is to maintain the water instream for its use instream. Although a pre-1973 water right claim was at issue, the case of the Matter of Dearborn Drainage Area (1988),

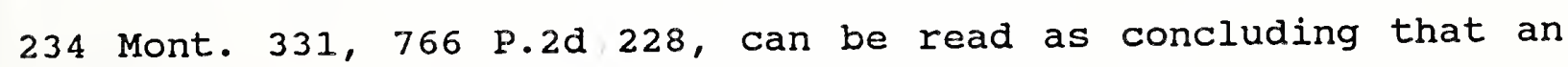
appropriation of water requires a diversion. Further, there is specific authority in subsection (b) of 85-2-102(1) for a public agency to reserve water under section 85-2-316, MCA. That authority coupled with an explicit provision for the reservation of minimum flows, levels, or quality of water in the reservation statute means it is highly improbable DFWP can appropriate instream flow through a water use permit. The most reasonable conclusion is that a reservation of water is the exclusive means for DFWP to protect instream flows through the appropriation of water. Consequently, DFWP must demonstrate that the water resource values warrant reserving minimum instream flows for fish, wildlife and recreation to establish the reservation is needed. 
The conservation districts and the BUREC have a different threshold test to establish that reservations of water are needed for their proposed irrigation projects since the project sponsors are eligible to apply for water use permits for irrigation. They must show a "reasonable likelihood" of pending competition for the available water, ARM $36.16 .107 \mathrm{~B}(2)(\mathrm{a})$, or that there are constraints that would restrict the project sponsors from perfecting a water use permit, ARM 36.16.107B(2)(c). Neither the conservation districts nor the BUREC have submitted any evidence showing restrictions on perfecting permits for irrigation projects and have not presented any evidence of future instate or out-ofstate competing water uses except for the competition from the instream reservation applicants. To the extent that this competition is sufficient to establish the need criteria for further considering the proposed irrigation projects, it, conversely, is sufficient to establish the need for considering the instream reservation requests.

The most salient point is that DFWP is absolutely dependent on the reservation process to establish minimum instream flows to the extent presently possible. The same is not true for the conservation district and BUREC irrigation projects. They are always eligible to apply for water use permits. The instream applicants have no second chance. Thus, the instream flow applicants have an unqualified need to obtain protection for instream values through a reservation. The irrigation projects do not have a similar need. 

There are significant public policy values to not reserving water for consumptive projects that do not pass a benefit/cost analysis or, at least, are not economically or financially feasible. If conditions change such that the benefits become greater than costs for some projects or they become economically or financially feasible, then the project sponsors can apply for water use permits. Also, instream reservations are the only reservations that can be reallocated to an applicant who is a qualified reservant if the Board finds part of an instream reservation is not required for its purpose and the applicant's need outweighs the need for the instream reservation. Section 85-2-316(11), MCA. All of these decisions would then be made at the time when the merits of specific irrigation projects can be most realistically assessed.

The disadvantage of granting reservations for irrigation projects that are not likely, under present analysis, to be developed is to discourage other feasible consumptive uses as they may develop in the future. Although reservations may be revoked or modified under the periodic reviews of section 85-2-316, MCA, it is poor public policy to place this burden on future consumptive users by reserving or tying up water for irrigation projects that probably will never be built. Reservations are not needed for irrigation projects that are not feasible.

DFWP has presented extensive evidence in its application and testimony demonstrating the fisheries, wildlife and recreational values that would be preserved by its reservation requests. This evidence, which was essentially uncontroverted, establishes the 

second prong of the need test for instream flows under ARM $36.16 .107 \mathrm{~B}(2)(\mathrm{b})$; that the water resource values warrant reservations.

The stream and river segments for which DFWP made application for reservations are those with the most significant fishery values in the Missouri River Basin above Fort Peck Dam. The DFWP approach was conservative with the 281 stream reach applications representing approximately $9 \%$ of the 2,739 streams in the basin that support a fishery or have the potential for a fishery.

The streams and rivers were chosen to protect the most valuable and significant fishery and recreational resources. The instream reservations will preserve a base flow for instream values by protecting the status quo of stream and river flows up to the minimum flows necessary to provide a healthy fishery. Minimum instream flows will maintain existing resident fish populations, will provide passage for migratory fish species in certain streams, will protect spawning and rearing habitats of both resident and migratory species, and will protect the production of aquatic food organisms and forage fish used as food by fish. The values to be protected are as varied and diverse as Montana itself. A brief summary, to the extent possible with 281 instream, one lake and one swamp reservation requests, of the fisheries, wildlife and recreation within the basin will illustrate the water resource values that warrant water reservations.

There are nationally recognized wild trout fisheries in the basin: the Gallatin, with its trophy-sized trout; the fabled 

Madison; the now widely recognized and extremely popular Missouri; the smith, combining its stunning canyon scenery with an exceptional fishery; the Big Hole and Beaverhead offering trophy fishing along with well used floating opportunities. Other streams provide trout fisheries in wilderness settings, some are local fishing holes primarily used by children, others are springfed streams highly valued by connoisseurs for their outstanding fisheries of selective trout, while many streams provide the only significant recreational fishing within a local region.

Many of the tributaries, along with nurturing a resident fishery, are spawning and rearing habitat for the fish in a mainstem river, lake or reservoir. For example, the trout spawning tributaries to the Missouri River in reach 3 are the Little Prickly Pear Creek, the Dearborn River and Sheep Creek.

The side-channels of the larger rivers, such as the Missouri River, are critical spawning and rearing habitat for the resident game and nongame species. The water flows in the relatively shallow side-channels are susceptible to dewatering in the more severe low water years.

The streams and rivers represent the most important recreational fisheries in the basin, including nationally and, even internationally, recognized recreational rainbow and brown trout fisheries. A magazine devoted to trout fishing recently published a feature article on "America's 100 Best Trout Streams". According to this article, six of America's best 100 trout streams, the Beaverhead, Big Hole, Gallatin, Madison, Missouri and Smith rivers, 

are in the Missouri basin.

The basin has excellent warm water fisheries, including the lower Missouri between the Marias River and Fort Peck Reservoir and the Musselshell River which flows from a coldwater fishery to a classic warmwater prairie stream. A number of rivers such as the lower Judith River present a transition from a coldwater to a warmwater environment.

other streams have special value because of their location. Many stream have high recreational value in their closeness to towns or cities. The Marias River in reach 2 is the only trout stream within a 50 mile radius in northcentral Montana. The Marias in reach 3 has a warmwater fishery that is especially attractive to residents of the western part of the state because of its relative proximity. Bean Lake, a popular and productive fishery, is the only natural lake of any significance in all of northcentral Montana. Big Spring Creek near Lewistown is one of the largest spring-fed streams in the state and is one of the most important trout streams in central Montana.

Trout anglers spent about \$50 million dollars in 1985 pursuing their sport in the Missouri River Basin above Fort Peck Reservoir. In addition, the net economic value was estimated in 1987 to be over $\$ 61.5$ million for the basin. The net economic value is the value of fishing determined by what people would be willing to pay over the amount they actually did spend to fish. These values are for fishing only. They do not include other water-based recreation, such as floating, camping, picnicking, swimming, bird 

watching, sightseeing and hunting.

However, recreational fishing valued in dollars is not the only value inherent in minimum instream flows. All forms of waterbased recreation, including fishing, are important to the human experience, providing both enjoyment and relief from day-to-day pressures. The preservation of the living residents of our rivers and streams is in itself a value, although it largely eludes monetary quantification.

The reservations would protect the more abundant game and nongame species, such as rainbow, brown, cutthroat and brook trout, mountain whitefish, burbot, walleye, sauger, kokanee, northern pike, shovelnose sturgeon, fresh water drum, cisco, smallmouth bass and black bullhead, as well as unique, unusual and rare species.

The American Fisheries Society and DFWP have designated certain fish as "Species of Special concern". This management tool signifies fish that have limited numbers in the state, limited distribution, or a limited amount of preferred habitat still available. Instream flows will protect the habitats of game fish species of special concern such as the westslope cutthroat trout, fluvial Arctic Graying, pallid sturgeon, and paddlefish, as well as nongame species such as sturgeon chub, sickelfin chub and the northern redbelly dace $x$ finescale dace hybrid.

The westslope cutthroat trout is a native Montanan, although genetically pure westslope cutthroat occupy only an estimated $1.1 \%$ of their historic range in Montana streams. The fish is now generally found in the isolated headwaters of tributaries. Another 

indigenous fish, the fluvial, or permanently stream dwelling, Arctic grayling is now restricted to the upper reaches of the Big Hole River. This is the only fluvial Arctic grayling population still remaining south of Canada and Alaska. It is now extinct in Michigan where it was also native. Fluvial Arctic grayling were once widely distributed and abundant in the Missouri River and its tributaries upstream from Great Falls. Fluvial Montana Arctic grayling are reduced in distribution to only about $8 \%$ or less of their historical range. This fish is now classified as a category 1 species, the final category before listing as a federal threatened or endangered species. The most likely significant factors in the fluvial Arctic grayling's decline in Montana are reductions in stream flows for irrigation, blockage by reservoirs and diversions, and flooding of streams by reservoirs. Therefore, maintenance of adequate water flows may be the most critical requirement for the continuing existence of the fluvial Arctic grayling in the upper Big Hole River.

The paddlefish is an ancient and unique relic, reaching back in geological time to the era of the dinosaurs. Paddlefish have been significantly reduced over their worldwide range. The Missouri River population is only one of six major self-sustaining populations in the United States. This population, in comparison with the other five remaining populations, has a superior growth rate and is older and more secure, due largely to the free-flowing characteristics of the Missouri River which provide essential and irreplaceable spawning areas for paddlefish. High spring flows 

trigger a migration of paddlefish from Fort Peck Reservoir to the critical spawning areas.

The pallid and shovelnose sturgeons, two other relics of the dinosaur era, reside in the Missouri River above Fort Peck Reservoir. The pallid sturgeon exists as a rare, ancient species over 200 million years old. However, the activities of man have pushed the pallid sturgeon to the bring of extinction in the last 50 years. The relatively unaltered Missouri River above Fort Peck Reservoir may be critical to the species' recovery, if not survival. The species has been recently listed as a federal endangered species. The average size of the healthy and vigorous shovelnose sturgeon population equals or exceeds the maximum size of those from other rivers in the Missouri and Mississippi basins. The paddlefish, pallid sturgeon, sicklefin chub, blue sucker, and sturgeon chub are species of special concern, with the pallid sturgeon, sicklefin chub, blue sucker, and sturgeon chub rare throughout their entire geographic range. Another species of special concern, the northern redbelly dace $\mathrm{x}$ finescale dace hybrid, is a peculiar minnow that produces only females as exact clones of the mother.

Maintaining the status quo of present flows will help avert a number of identified problems, such as thermal pollution in the Madison River below Ennis Dam, where additional reductions in river flows could mean fatal summer water temperatures for trout. Stream conditions can also be improved highlighting the need to protect base minimum flows. For example, recent upgrades in Bozeman's 

sewage treatment plant have allowed the fishery in the East Gallatin River to prosper once again. other streams suffering pollution from old mining wastes could recover with reclamation. The Boulder River, a tributary to the Jefferson River, and the Dry Fork of Belt Creek are examples of streams with this potential. Other rivers, such as the Jefferson, Sun, and Musselshell, have unused potential because of dewatering by consumptive uses that could be realized if adequate minimum flows ever become available. Spawning tributaries have been rehabilitated such as Willow spring Creek, now a spawning tributary for the Jefferson River's rainbow trout. This illustrates the potential that exists when adequate water is available at critical times.

The requested flows are also necessary to help protect the habitat for those numerous wildlife species which depend on the streams and their riparian zones for food, water and shelter, including the bald eagle, peregrine falcon, whooping crane and grizzly bear, all of which are federally listed threatened or endangered species. Specifically, Antelope Butte Swamp, a perennial wetland area in the Blackleaf Wildlife Management Area along the east front of the Rocky Mountains, is an example of the dependance of wildlife on riparian habitat. Grizzly bears in particular are drawn to the swamp during the spring to feed on succulent plants that grow in the moist environment of the swamp. Canadian geese nest on islands in the Missouri River where adequate flows are needed to protect the nests from mammalian predators. Bald eagles concentrate at the mouth of Trout Creek on the Missouri 
River above Hauser Reservoir during the fall kokanee spawning season.

These water resource values justify the minimum instream reservations requested by DFWP, and show the need for the reservations.

Amount. The Board must find "amount of water necessary for the purpose of the reservation". Section 85-2-316(4)(a) (iii). The Board's rules, $A R M \quad 36.16 .107 \mathrm{~B}(3)(\mathrm{a})$, require a finding "that the methodologies and assumptions used to determine the requested amount are accurate and suitable".

For a reservation process covering the immense and water resource rich Missouri River Basin above Fort Peck Reservoir, the DFWP needed an accepted and proven minimum instream flow setting method that could be practically applied to the task at hand. DFWP selected and applied what is called the Wetted Perimeter Method to the majority of the streams and rivers for which instream reservations are requested, with other methods used where they were better suited to a particular type of stream or where other constraints prevented the application of the Wetted Perimeter Method.

The details of the Wetted Perimeter Method have been carefully described by DFWP throughout this reservation process, including in the proposed findings of fact. The method relates one critical element needed for a fishery, the food producing capacity of a stream, to stream flows. Stream riffles are the primary food producing areas of Montana's stream-dwelling game fish. They are 

distinct segments of streams that are readily distinguished, and they are the area of a stream that is most sensitive to flow reductions. The amount of riffle area, wetted perimeter, covered with water is plotted as flows increase. The rate of increase in wetted perimeter is a function of the stream channel profile. As flows increase, there is a point where the stream approaches its maximum width, with the water starting to move up the sides of the banks and where the rate of increase of the wetted perimeter starts to decline more rapidly with increases in flows. Beyond this point, called the upper inflection point, large increases in flow result in only small increases in wetted perimeter. The upper inflection point is the minimum flow that protects most of a stream's fishery values. On the average, the upper inflection point flow equals about $40 \%$ of the average annual flow of a stream.

For many streams, there is usually a lower inflection point on the graph of wetted perimeter versus flows. This lower inflection point marks a change in the stream channel's profile. It is the flow at which the water starts to move up the sides of the active channel of a stream. This point does not measure the minimum flow required for a heathy fishery but maps a change in the stream channel profile more than anything else.

other methods for setting minimum instream flows were also evaluated and studied by DFWP before the Wetted Perimeter Method was selected as the principal instream flow setting method.

The best and most accurate means of determining minimum flow needs is to directly observe the response of fish populations to 

flow variations over a period of many years. This Biological-Flow Relationship Method was impractical to use in this reservation process because of the intense data requirements and time commitment, although it was used where studies have been done. The flow requests for reach 2 of the Gallatin River, reach 4 of the Madison River, Narrows Creek, and the Missouri River Mainstem reaches 2 through 6 are based totally, or partially, on biological studies.

The wetted Perimeter Method is one of the methods designed to develop minimum flow recommendations by examining a characteristic of streams that is related to habitat as it changes with flow. Two other methods of this type, The Habitat quality Index and The R-2 cross method, were tested and evaluated by DFWP, but were found unsuitable for use in Montana. The Wetted Perimeter Method was studied by both DFWP and Montana State University. These studies support the validity of the minimum flow recommendations generated by the Wetted Perimeter Method. It is a well recognized and commonly used minimum flow method, particularly in the Pacific Northwest and Rocky Mountain areas which are the areas in the United states most similar to Montana.

The United States Fish and Wildlife Services Instream Flow Group, a recognized leader in the application and development of instream flow methods, has found the Wetted Perimeter Method to be the type of method appropriate for setting minimum flows for protecting instream resources in state water allocations like this reservation process. In contrast, the more advanced incremental 

methods, such as the instream flow group's Instream Flow Incremental Method, are designed for measuring trade-offs for water projects, such as release patterns from reservoirs, rather than providing minimum flow recommendations. The incremental methods require a costly, complex and time-consuming analysis. These methods were rejected as having limited practical application to the water reservation process.

The Wetted Perimeter Method was the primary method used, with other methods chosen when they were either more suitable or there were constraints on the use of the Wetted Perimeter Method. For example, a fixed percentage technique was used for 27 stream reaches because of time and access limitations and a base flow approach, which is more applicable to the relatively constant flows of spring-fed streams, was applied to 17 streams.

As much attention was paid to the application of the Wetted Perimeter Method as to its selection. DFWP personnel were trained at workshops conducted by DFWP, often in conjunction with the United states Geological survey (USGS). The data was collected by 12 teams, typically lead by a field biologist, and the process was governed by written procedures and standards. A number of checks and balances were used so the results would be accurate and reliable. All data was reviewed by Fred Nelson, the individual in DFWP responsible for instream flow methods development and application, and Mr. Nelson consulted with team leaders on the application of the methods. The upper inflection point was generally selected as the instream flow recommended, with the 

biologist who collected the data and who was familiar with the stream making the selection of the inflection point from the wetted perimeter graph. The exercise of professional judgment is a necessary component of the Wetted Perimeter Method, as it is for any instream flow method. Flows lower than the upper inflection point, but never higher, were sometimes chosen by the responsible fishery biologist based on a professional evaluation that the lower request was sufficient to provide minimum instream flow protection. Lower inflection point flows were made only for streams suffering from dewatering and when the resource or potential resource values were less significant.

The riffles selected for instream flow determinations were generally at the lower end of a stream reach where the reservations would be monitored. The resulting minimum flows recommended, therefore, represent the needs of the fishery in the lower portions of designated stream reaches.

The only direct expert testimony on the suitability and accuracy of the Wetted Perimeter Method was the testimony of Fred Nelson, Robert G. White and Virginia G. Thomas, all supporting the method for use in establishing minimum instream flows for reservation applications.

The testimony of Thomas A. Wesche, although apparently intended to be critical of the wetted Perimeter Method, never concluded the method or its assumptions were not suitable or accurate. Wesche felt there was not enough support for the assumption that macroinvertebrate production in a stream is a 

limiting factor. As a consequence, he suggested more complex methods using a variety of environmental factors. However, he never stated that any other method using more variables would be practical for Montana's reservation process or would produce better results. In effect, his expert opinion seemed to be that nature is complex, therefore a more complex model or method must be better. He did not testify to a better method.

Wesche also felt that the wetted Perimeter Method was based only on the quantity of food production and it would be better to have a model that considered other habitat parameters such as water velocity and depth. Although this was described as a weakness, he did not conclude that another method produces better results for setting minimum instream flows. Again, his testimony was only to the effect that some other method, if more complex, might be an improvement over the Wetted Perimeter Method. There was no consideration of the fact that flows recommended by the wetted Perimeter Method also provide water velocity and depth in a stream riffle where food production occurs.

Wesche correctly concluded that some channel configurations are not suited to the Wetted Perimeter Method. However, DFWP understands this and applied the method with professional judgment. For example, the method was not applied to braided sections of rivers. It was also not applied to spring creeks where the stability of flows precludes its use.

Other criticisms were made of DFWP's application of the Wetted Perimeter Method, generally claiming that the wrong riffle section 

may have been selected or that the inflection point was not properly chosen. All this criticism was based on a review of DFWP's application and was not based on any personal professional knowledge of the streams and rivers involved. DFWP forcefully rebutted these claims.

In summary, the application of DFWP and the testimony presented convincingly support a finding that the methods and assumptions used by DFWP are accurate and suitable. There was, in fact, no testimony to the contrary.

Water Availability. Showing that water is available is not a criteria for instream reservation applications under the statutes and rules, although such a showing is applicable to consumptive use reservation applications because it is incorporated as part of the requirement that a reservation applicant must show the reservation will not adversely affect existing water rights.

For any complete application, including those for conservation district projects, ARM 36.16.105B(2) requires that "[a]n analysis of the physical availability of flows or aquifer yields must be provided." For gaged streams, the available water resources data must be presented in a specific manner and for nongaged streams the flows must be estimated with a technique approved by DNRC. DFWP met this application requirement with a final written report by the USGS entered into evidence through Charles Parrett, U.S. Geological Survey, as DFWP Exhibit 12 and supplemented with additional testimony for 9 streams for which data was not available in time to include in the report itself. Although the base period of record, 
1937 to 1986, was criticized, a comparison with long term records of 75 to 101 years shows the base period average annual flows are closer to the long term averages than to the averages for the period of record advocated, 1930 to 1990. The streamflow measurement techniques used by the USGS are generally accepted by the hydrology communities.

There is no requirement that an instream flow applicant prove that water is always available at all times to meet the amount requested. An instream reservation applicant need only prove the amount needed for the reservation. However, a consumptive use reservation applicant does need to show that water is available, at least often enough to make the project feasible, to show that the consumptive use will not adversely affect existing water rights. This requirement will be discussed later in more detail.

public Interest. This criteria provides for direct comparisons of competing reservation applications. An analysis of proposed instream reservations that do not have competing reservation requests for the same water is also provided.

The Board's rule, ARM 36.16.107B(4), implementing the use of the public interest criteria provides:

For the board to adopt an order reserving water, it must find, in its judgment and discretion, that the reservation is in the public interest, as required by 85$2-316(4)(a)(i v)$, MCA, based on a weighing and balancing of the following factors, after making a specific finding for each factor: ....

The listed factors are a benefit and cost analysis, a consideration of any reasonable alternative with greater net benefits, a consideration of any irretrievable loss of a natural 

resource, a consideration of any adverse impacts to public health, safety and welfare, and a consideration of any other factors. ARM 36.16.107B(4) (a) through (f).

The first factor, a benefit and cost analysis, provides for a direct monetary comparison by adding all direct and indirect benefits and subtracting all direct and indirect costs for each reservation that competes for the same water with another reservation. This comparison is made with those benefits and costs that can be reasonably quantified. Benefits and costs that cannot be reasonably quantified must also be weighed in the balancing.

All of the conservation district proposed projects compete with instream reservation requests. On the other hand, the instream reservation requests of the Department of Health and Environmental Sciences (DHES) and BLM, the claimed Murphy Rights of DFWP, the claimed reserved water rights of the BLM for the Wild and Scenic portion of the Missouri River, the hydropower claims of MPC and BUREC, the claims of existing water users and claims of Indian Tribes are all not in competition with each other for the purposes of this analysis. Existing rights are protected because any reservations will be subject to them. All instream claims and reservation requests and downstream existing claimed rights, including claims for hydropower, use the same water. They are complementary to each other.

DFWP has compared its reservation requests with the competing conservation district projects in a benefit and cost analysis in its proposed findings of fact. The value of water for each 

irrigation project was determined by DRNC, although the analysis was based on a number of assumptions favorable to the projects. The analysis assumed the most profitable crop, alfalfa, would be grown, the highest possible yields would be obtained, water would be available eight years out of ten, and alfalfa prices would not be depressed. As a result of these assumptions, the calculated irrigation values of water are high.

The recreation values of water were derived using the Contingent Valuation Method of valuing nonmarket goods, which is a widely accepted nonmarket method, especially for water resource uses. Although DNRC in the Final EIS computed the hydropower values per acre-foot based on replacement values of both $50 \mathrm{mills}$ and 100 mills per kilowatt-hour, DFWP used 75 mills as the most appropriate hydropower replacement value that was supported by expert testimony. Also, the value of water for recreation lost to consumptive use was calculated only for the stream reach first impacted. Subsequent losses to downstream reaches were not added. This approach was conservative and undervalues losses to recreation.

Using the above assumptions, eleven projects have net benefits greater than the indirect cost to instream uses for recreation and hydropower. However, when the other identified and unquantified indirect costs of these projects are included, none of them pass the benefit and cost analysis. For example, project GA-201 would divert arsenic-laden water from the Madison River into the Gallatin River drainage and will cause thermal pollution in the lower 
Madison River, likely causing massive fish fills in some years. When both of these unquantified costs are added to the equation, the costs to instream uses incurred by hydropower, recreation, water quality and fish and wildlife exceed the irrigation benefits of project GA-201. The symmetry of the benefit and cost analysis means that all of the competing instream reservations have net benefits greater than net costs.

Further, for the 242 instream reservation requests that do not compete with proposed consumptive use reservation requests, the benefit of protecting the existing instream uses by maintaining status quo flow levels was calculated in the expert witness testimony of John Duffield. Reservations on these streams will provide direct benefits to instream uses through legal protection for continued instream water use. This direct benefit is on the order of $\$ 32$ million per year. Not considering these direct benefits of instream reservations would mean that instream values are recognized only when a competing project is proposed.

DFWP recognized for a number of proposed projects that have been rated as at least marginally financially feasible, it may be in the public interest to grant reservations to some of these projects if they are junior to the instream reservations. These are the projects that do not have significant impacts on instream flows, would not significantly worsen existing water quality and aquatic life, and would not adversely impact water levels in canyon Ferry Reservoir. It would be in the public interest to grant reservations, junior in priority to the instream flows, to the 

projects listed in the proposed findings of fact.

So far in this summary of DFWP's analysis of the benefit/cost factor of public interest, only the quantified benefits and costs have been used. Unquantified benefits include those flowing from protecting the natural resource of our rivers and streams in themselves. This includes nationally and locally renowned trout rivers and stream with their spawning tributaries, excellent warmwater fisheries, the ancient paddlefish, the endangered pallid sturgeon, and the native westslope cutthroat trout and fluvial Arctic grayling whose range has been drastically reduced. Recreational floating in the smith River and other rivers will benefit. Riparian plant communities dampen flooding through erosion control and provide habitat for wildlife and birds. Instream flows preserve biological, recreational, scenic and historic values of streams and rivers.

Adequate flows will maintain water quality, another benefit unquantified in monetary terms, but extremely significant. The carcinogenic impact of arsenic concentrations in the Madison River commands a response and the answer is in the diluting flows of the Jefferson, Gallatin and other rivers and streams.

Instream flows will help maintain hydropower generation capacity on the Missouri River, will support the expanding tourist industry of Montana, will help maintain water levels at existing headgates, and provide a legal buffer for existing water uses from future competing water development.

There will be some direct administration costs for DFWP in 

monitoring and protecting reservations. Industry, such as mining, may have additional indirect costs in obtaining new water but these costs will not be significant. Instream flow reservations will not have adverse impacts on existing irrigation water rights. DFWP will have the same right as any junior right holder to object to changes in senior rights that are adverse to an instream reservation. To the extent this is an indirect cost, the past history of DFWP in protecting its Murphy rights and Yellowstone reservations shows that it is de minimus, and not significant in comparison to other quantified benefits and costs.

In summary, the benefits of granting all instream flows exceed the indirect costs to foregone irrigation and all other direct and indirect costs. This identifies the optimal set of reservation requests with the greatest net benefits. Consequently, there are no other reasonable alternatives with greater net benefits. ARM $36.16 .107 \mathrm{~B}(4)(\mathrm{C})$.

However, future new water use permits will incrementally cause an irretrievable loss of water quality, fisheries, and opportunities for recreation if instream flows are not protected with water reservations. ARM 36.16.107B(4)(d). The competing conservation district projects demonstrate the likelihood of this loss.

Significant adverse impacts to public health, welfare and safety must be considered as a factor. ARM 36.16.107B(4)(e) . Many of the conservation district projects will have adverse impacts on aquatic life by further dewatering streams already dewatered by 

existing water uses. These impacts will be severe on the Jefferson River, the Boulder River, the Missouri above Canyon Ferry Reservoir, the Smith River, the Sun River, the lower reaches of Belt Creek, the Marias River and the Teton River. In addition, the cumulative impact of all the proposed projects above canyon Ferry Reservoir could lower reservoir levels four to six feet in the driest year. Consumptive use reservations in the Missouri River Basin will increase the concentration of arsenic in the Missouri River and adjacent ground water systems. This will aggravate the substantial health risk that already exists from arsenic concentrations in the Missouri River. On the other hand, the impacts of instream flows to public health, welfare and safety are positive and beneficial.

The unquantified benefits and costs and other factors involved in the public interest criteria weigh significantly in favor of protecting instream flow values. The benefit of providing a legal baseline or minimum protection of the aquatic and riparian ecology of many of Montana's most significant waterways is enormous. Benefits to society do not depend solely on the extent they can be described directly in economic benefits to people. Preserving our natural and wild heritage for ourselves and the future is reason enough to do so. It is fortunate in this process that the strictly economic benefits lend full support to a decision to help protect the irreplaceable natural treasures of the most wondrous of Montana's streams and rivers.

Management Plans. DFWP has a management plan for measuring, 

protecting and reporting on instream uses as required by ARM 36.16.107B(7). This plan is based on the DFWP's experience with monitoring and protecting its Yellowstone reservations and Murphy rights.

The adequacy of DFWP's management plan does not seem to be in dispute. However, the manner in which instream flows will be monitored and measured deserves some emphasis. DFWP has applied for instream reservations for stream segments or "reaches". These reaches describe the lengths of streams or rivers where fisheries, wildlife and recreational values warrant protection. The needed flows were determined at a point on each reach, generally near the downstream end of the reach. The instream reservation will be measured and monitored at the point where the flow was derived or at some other point downstream but within the reach. The flow requested is the minimum flow needed in the stream at the point of its determination and does not represent the flow requirements throughout the length of the stream reach.

The monitoring of instream flows at a downstream point in the reach is a practical approach to protecting fisheries, wildlife and recreational values within the reach. However, the monitoring will only detect changes in flows at the point of monitoring. Changes in use, such as changes in points of diversion, occurring completely above the point of monitoring cannot, therefore, adversely affect the instream reservation unless more water is consumed. This eliminates most objections that have been made based on an assumption by objectors that instream reservations 

could prevent senior appropriators from changing a point of diversion upstream. There are limited but justified exceptions. A change in a point of diversion from a mainstem river to a tributary protected by a reservation would result in decreased flows at a monitoring point near the mouth of the tributary. This change could adversely affect the instream reservation on the tributary and DFWP could object to protect the tributary reservation.

In over twenty years of protecting Murphy rights and almost fourteen years of protecting Yellowstone basin reservations, DFWP has objected to only 8 changes in use. These objections prevented none of the changes, although one change application was withdrawn. Thus the impact on existing water rights has been negligible, if measurable at all.

For conservation district projects, the Board must find the project sponsor has the capability to feasibility finance the project with reasonable diligence as part of a management plan. ARM 36.16.107B(7). Only those projects that are at least marginally feasible financially can meet this requirement.

Affect on Existing water Rights. The Board must find that a proposed water reservation, as stated in section 85-2-316(9)(e), MCA, "may not adversely affect any rights in existence at that time." See also, ARM 36.16.107B(8).

This requirement is met by instream reservation requests. The instream reservations cannot adversely affect existing water users because no water is removed or consumed. The instream reservations 

will only preserve the present status quo of stream flows against future additional consumptive uses of water that would erode or further erode the minimum instream flows needed for healthy fisheries. They do not compete with other instream uses, but would be complementary or concurrent uses of the same water. Instream flow rights are not additive.

Nearly all of the conservation district projects will most likely adversely affect existing water rights. Although this determination cannot be conclusively made until the final adjudication of existing rights, the claims of existing water users are sufficient to prevent the Board from concluding there will be no adverse affect. Therefore, the granting of any new irrigation reservations must be conditioned on a determination of water availability, which will not be known until the statewide adjudication process is complete.

A number of claimed water rights are particularly controlling. If MPC's largest claimed water right of 10,000 cfs for hydropower generation at Cochrane Dam is adjudicated as claimed, future consumptive uses upstream will be severely limited. Water would be available in only about one year in ten during April through July and about five years in ten during May and June. Water would not be available from August through March. The BUREC has substantial claimed water rights at canyon Ferry. Irrigation projects above Cochrane Dam and Canyon Ferry will potentially adversely affect existing water rights except when water is spilling over the dams. The large proposed irrigation project on the Madison River, 

GA-201, will adversely affect DFWP's claimed Murphy right on the Madison in six years out of ten. The Virgelle project of the BUREC will adversely affect BLM's claimed reserved rights in the wild and Scenic portion of the Missouri River unless the project is conditioned on the maintenance of these instream flows. BUREC has acknowledged any reservation granted for the virgelle project should be junior in priority to the instream flows in the wild and Scenic portion of the Missouri River. The instream reservation requests of DFWP in reaches 5 and 6 of the Missouri are essentially identical to BLM's claimed reserved rights and would also be protected by conditioning the reservation for the virgelle project.

Reservations for the conservation district irrigation projects cannot be granted unless they are conditioned to existing water rights and conditioned to a determination of water availability through the statewide adjudication process.

\section{CONCLUSION}

The instream reservation requests of DFWP meet all of the criteria established in the reservation statute and implementing Board rules, are in the public interest in themselves and when compared to competing consumptive use irrigation projects, are complementary to the instream reservation requests of DHES and BLM, and cannot adversely affect existing water rights. They should be granted subject only to the municipal reservations. The reservation requests for conservation district irrigation projects are not in the public interest when compared to the competing instream reservation requests of DFWP and DHES, will most likely 
impact existing water rights, and the projects that are not at least marginally financially feasible are not likely to be pursued. Reservations for these projects should not be granted except for projects that are at least marginally financially feasible and whose potential competition with instream reservations is not substantial. These latter projects could be granted in the public interest if they are junior to the instream reservations. The BUREC project at Virgelle could be granted if it is conditioned to instream flows and does not violate water quality standards. The City of Bozeman has not yet demonstrated a need for the amount of its reservation request, but the reservation could be granted subject to appropriate conditions.

This Board, at long last in the management of water in Montana, has an opportunity to protect the natural and wild heritage of our rivers and streams in the basin.

As Bill Thomas, in his poem "The River", cautions and advises:

Before there was man, there was the river...

a complete ecosystem...

a vital link to creation.

Whenever we endanger the quality of our river,

we indeed are doing great harm to ourselves.

DATED: April 8 1992.

Department of Fish, Wildlife and Parks

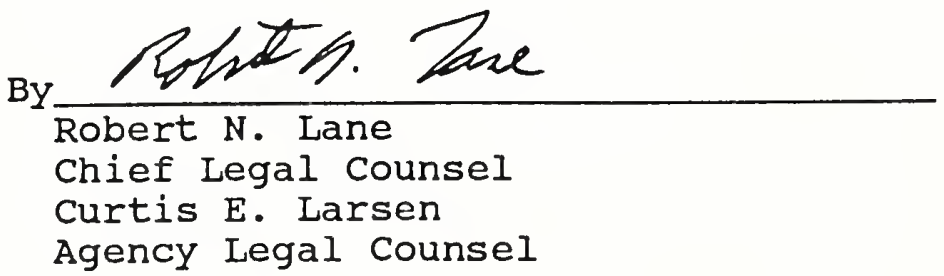




\section{CERTIFICATE OF SERVICE}

I hereby certify that on the 8 th day of April, 1992, the Montana Department of Fish, wildlife and Parks' (Department) filed the attached DEPARTMENT OF FISH, WILDLIFE AND PARKS' BRIEF OF DFWP IN SUPPORT OF ITS INSTREAM APPLICATIONS AND IN OPPOSITION TO THE RESERVATION APPLICATIONS OF THE CONSERVATION DISTRICTS, THE BUREAU OF RECLAMATION AND THE CITY OF BOZEMAN - A COpY was served by hand-delivering the original and two (2) true and accurate copies to:

Peter T. Stanley

$\%$ Department of Natural Resources and Conservation

1520 East Sixth

Helena, MT 59620

and by depositing true and accurate copies, postage prepaid, in the United states Post office at Helena, Montana, to the following locations:

Loren Tucker

P.O. Box 36

Virgnia City, MT 59755

J. B. Anderson

$112 \mathrm{~S}$. Washington

Dillon, MT 59725

Gary Spaeth

111 N. Broadway Ave.

Red Lodge, MT 59068

Holly J. Franz

Gough, Shanahan, et. al.

P.O. Box 1715

Helen, MT 59624-1715

Monte J. Boettger

507 Montana Bldg.

Lewistown, MT 59457

Cindy Younkin

P.O. Box 1288

Bozeman, NT 59715

Ted J. Doney

P.O. Box 1185

Helena, MT 59601
Steve Brown

1313 11th Avenue

Helena, MT 59601

Paul B. Smith

P.O. Box 565

Boulder, MT 59632

James Hubble

P.O. Box 556

standford, MT 59479

Mona Jamison

P.O. Box 1698

Helena, MT 59601

Dale Schwanke

P.O. Box 2269

Great Falls, MT 59403

Keith strong

P.O. Box 1566

Great Falls, MT 59403

Carl Davis

P.O. Box 187

Dillon, MT 59725 

W.G. Gilbert III

P.O. Box 235

Dillon, MT 59725

John Bloomquist

P.O. Box 1302

Dillon, MT 59725
John Chaffin

P.O. Box 31394

Billings, MT 59107

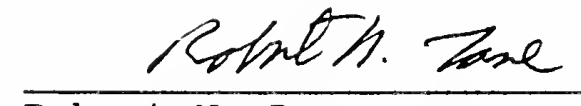

Robert N. Lane

Chief Legal Counsel 
